\title{
Erratum to: Rotator Cuff Tear and Glenohumeral Instability: A Systematic Review
}

\author{
Mufaddal Mustafa Gombera MD, Jon K. Sekiya MD
}

Published online: 9 December 2014

(C) The Association of Bone and Joint Surgeons ® 2014

Erratum to: Clin Orthop Relat Res (2014)

472:2448-2456

DOI 10.1007/s11999-013-3290-2

The first author for the published study, "Rotator Cuff Tear and Glenohumeral Instability: A Systematic Review" legally changed his name. The author's name is now Mufaddal Mustafa Gombera MD.

The authors appreciate your acknowledgement of this name change.

The online version of the original article can be found under doi:10.1007/s11999-013-3290-2.

M. M. Gombera, J. K. Sekiya ( $\square$ )

Department of Orthopaedic Surgery, University of Michigan,

MedSport, 24 Frank Lloyd Wright Drive, Lobby A,

PO Box 0391, Ann Arbor, MI 48106-0391, USA

e-mail: sekiya@med.umich.edu 